Wilfrid Laurier University

Scholars Commons @ Laurier

Geography and Environmental Studies Faculty

Publications

Geography and Environmental Studies

$3-9-2012$

\title{
Contextualizing the Global Nursing Care Chain: International Migration and the Status of Nursing in Kerala, India
}

Margaret Walton-Roberts

Wilfrid Laurier University, mwaltonroberts@wlu.ca

Follow this and additional works at: https://scholars.wlu.ca/geog_faculty

Part of the Geography Commons

\section{Recommended Citation}

Margaret Walton-Roberts. Contextualizing the Global Nursing Care Chain: International Migration and the Status of Nursing in Kerala, India, Global Networks 12, 2 (175-194), (2012). https://doi.org/10.1111/ 1471-0374.00012

This Article is brought to you for free and open access by the Geography and Environmental Studies at Scholars Commons @ Laurier. It has been accepted for inclusion in Geography and Environmental Studies Faculty Publications by an authorized administrator of Scholars Commons @ Laurier. For more information, please contact scholarscommons@wlu.ca. 


\title{
Contextualizing the global nursing care chain: International migration and the status of nursing in Kerala, India
}

\author{
Margaret Walton-Roberts \\ International Migration Research Centre \\ Wilfrid Laurier University, \\ Waterloo Ontario Canada. \\ mwaltonroberts@wlu.ca
}

Forthcoming in: Global Networks: A Journal of Transnational Affairs

\begin{abstract}
In this paper I explore the issue of nursing status in Kerala, India and how over time a colonial discourse of caste-based pollution has given way to a discourse of sexual pollution under expanding migratory opportunities that remove women from local community surveillance. Based on survey and qualitative research findings, I caution that the improving occupational status of nursing in India is not directly mapped onto social status, and this is particularly evident in regards to the matrimonial market. In light of these findings I argue that Global Nursing Care Chain (GNCC) analysis must assess more than just workplace contexts in order to conceptualize how Global Care Chains (GCCs) interlock, and how they are differentiated from each other.
\end{abstract}

Keywords Global nursing care chain (GNCC), gender, migration, India, Kerala

The concept of the 'global care chain' (GCC) (Hochschild 2001; Ehrenreich and Hochschild 2002) has been used to great effect in linking the structural and personal dimensions of feminized migration under conditions of welfare restructuring. Nevertheless, GCC research has been criticized for its lack of spatiality, particularly in tracing regional migration flows (Parreñas, 2009, this issue), and for its limited focus on one type of feminized migration in one type of setting, namely domestic workers in private homes. Yeates $(2004,2009)$ argues that extending the GCC concept to other care sectors and spaces-particularly nursing and institutional sites of care-will enhance its analytical and explanatory power. While female care workers face similar 
structural processes across different occupational sectors there is no clear sense of universal commonality between nurses and domestic workers. In this regard the analysis of different care workers needs to be demarcated, but at the same time, as Choy (2003) argues, they are also bound together through the racialized and feminized stereotyping experienced in the work place. Certainly a comprehensive view of care chains will have to identify how various types of care work are interlocked, even though they are distinctive in terms of the training, remuneration, regulation and institutionalization of the sector. Some scholars are already sensitized to how these seemingly distinctive occupational divisions are interlocked. For example in Canada the live-in caregiver program is already well known as a channel for Filipino nurses to enter Canada to work as live-in-caregivers, and then after several years, when they meet the requirement for permanent residence, they can attempt to reenter the nursing profession (Kelly and Addario 2008; Pratt 1999). The Canadian case demonstrates that while the idea of GCCs reflects an occupational division, the reality is far more complex depending upon the spatial and policy context, and it echoes Cheng's (2004) and Anderson's (2009) call to assess the contextual nature of identity construction in care that moves beyond the workplace into other spheres. In this paper I highlight the power of discursive processes that devalue the status of female nurses who, though increasingly integrated into migrant networks that offer enhanced economic rewards, still have to contend with social processes that operate to undermine their status especially in the realm of matrimony.

\section{Conceptualizing nurse migration}

The migration of nurses is differentiated from that of domestic workers because nurses possess credentials that are managed by professional bodies, and tend to be employed in institutional rather than private settings. Nevertheless, within a political system of health and welfare restructuring care, especially that involving 'body work', continues to be devalued (Dyer et al. 2008; Van Dongen and Elema 2001). In this context it has been argued that the use of internationally educated nurses (IENs) furthers the over-commoditization of care (Folbre 2005); adds to the 'churning' already present in nursing labour markets (Gordon 2005), while further marginalizing the relative power nurses hold within health care systems (Smith and Mackintosh 2007). In addition IENs also face the challenge of overt workplace discrimination (Dicicco- 
Bloom 2004). Despite, or perhaps because of, these factors the use of IENs continues to provide a 'quick fix' policy response for nations that have failed to effectively train and retain domestic nurses (Brush 2008; Kingma 2006). This transmission of qualified nurses arguably acts as a perverse form of aid from the poorest to the richest nations that further entrenches global health inequality (Yeates 2009), and potentially reproduces the profession's marginality (Smith and Mackintosh 2007). Thus the migration of health workers can act as both an expression and perpetuation of structural deficiencies in health systems globally (Stilwell et al. 2003; Connell 2008). At the discursive level the status of nurses can also be devalued, despite their improved income earning potential, and in the Indian context poor nursing status continues to be a central push factor in the international migration of nurses. Status, therefore, is a global concern for the nursing profession, but it operates variably at different scales and in different places. In this paper I address the regional scale in one sending region, focusing on Kerala in south India.

Nurse migration is a useful illustration of the institutionalization of migration (Goss and Lindquist 1995), since it calls upon various agents and states in order to facilitate the orderly transfer of skilled personnel between different state jurisdictions. Despite the value of the institutionalized view of migrant networks, which incorporates multiple scales into the analysis, in the area of care work this approach lacks a politicized feminist reading of the broader intersections between the sphere of production and reproduction. On the other hand Yeates' (2004, 2009) extension of the GCC to incorporate nursing, encourages research that is comparative, assesses how various GCCs interlock, explores the institutional and policy dimensions of care, and surpasses methodological nationalism by focusing on transnational dimensions of social policy. This approach provides both a theoretical and methodological guide with regards to assessing various inputs and outputs along the nursing care chain, and also 'contribute[s] to the development of a feminist theory of services globalization' (Yeates 2004: 370). Using the GNCC approach in the case of the migration of Indian nurses encourages a comprehensive assessment of feminized labour migration from a transnational viewpoint, but also maintains sensitivity to feminist criticisms of the structural dimensions of the global economy as well as the historical and household context.

\section{The social and occupational status of nurses and nursing}


The occupational status of nursing globally has long been haunted by concern over issues of autonomy and professional status, especially in regard to relations with physicians (Salvage 1985). A central part of concern with status is wrapped up with the 'body work' of intimate care that is a central dimension of nursing. Van Dongen and Elema (2001) have highlighted the transformation of nursing work towards clerical and institutional tasks, and away from the traditional dimensions of body care and touch, which have increasingly been passed onto nursing aids and orderlies (which itself represents an important element of the interlocking of different GCCs). For geriatric nurses in the Netherlands touch is both a technical and emotional aspect of care that is central to their job, but also a task that nurses cite as one reason for their relative devaluation in the nursing hierarchy (Van Dongen and Elema 2001).

In South Asia this aspect of nursing work is also devalued in part because of its contravention of symbolic taboos. Here touch and dealing with polluting bodily fluids is already historically structured as the central reason why nursing was stigmatized (Nair and Healey 2006). In Bangladesh for example, it has been observed that nurses shun important elements of care that require physical contact with the patients and the 'dirty work' of nursing such as washing, changing bedpans and attending to wounds. Hadley et al. (2007) explore how government hospitals can become sites where nurses establish their higher status by shunning 'dirty work'; leaving it instead to family members and hospital support workers. Hadley and Roques (2007) found that nurses in Bangladeshi government hospitals spent only 5 per cent of their time with patients, and that by relieving themselves of related 'dirty work', these nurses were able to maintain prestige relative to patients, their families and patient carers. Zaman (2009) sympathetically contextualizes this situation by highlighting the challenges nurses in Bangladesh face in coping with a high ratio of patients, dealing with threats and intimidation from patients' families, difficult relations with doctors and interns, as well as the problems stemming from nursing being associated with immorality due to women working at night, outside the home, and engaged in 'dirty' work with low caste men and women. Similar issues are also evident in Kuwait and other Middle Eastern nations where 'nurses are considered maids for patients and assistants for physicians' (Al Jarallah et al. 2009: 70). 
Corresponding concerns emerge in India with regard to the lack of nursing patients receive and the expectation that family members will provide patient care, but this is posited as a reflection of the shortage of nurses as opposed to their refusal to perform such duties (Kalita 2003). Nevertheless, similar stigmatization of core nursing responsibilities has been noted in India (Jeffery 1988; Nair and Healey 2006; Raghavachari 1990; Somjee 1991). While this is arguably subsiding as nursing is seen as a more respectable profession (Nair and Healey 2006; Percot 2007), the relative status of nursing in India is still perceived poorly compared to OECD countries. Recent research in Chennai India suggests workplace demands, especially associated with HIV, restricts both the nurses' ability to manage case loads and increases the preexisting devaluing of the profession: 'Nurses are basically trained as helpers to physicians in a governing system that systematically subjugates nursing to medicine' (Phillips quoted in Shukla 2009).

\section{India and Kerala's role in the GNCC}

Despite the number of books and papers recently published on the international migration of nurses (Connell 2008; Kingma 2006; Tschudin et al 2008; Yeates 2009), there are relatively few academic reviews of India's role in the supply of nurses for global export. The literature that does focus on India provides a rich analysis of nurse's own experiences of migration and overseas employment (George 2005; Percot 2007), but few take a meso- or macro- approach to the current transformations occurring in India with regard to nursing education, training and the changing role of relevant institutions, and how this intersects with household decisions. Recent evidence suggest that India is following the example of the Philippines in that it is seeking to boost its ability to provide qualified nurses to the international market (Brush and Sochalski 2007; Khadria 2007). For example, scholars in the southern Indian state of Kerala, long known for its tradition of nursing and international nurse migration, have recently begun to examine the Philippines' approach to the management of international migration and remittances and how this might inform Kerala's policy (Rajan and Mishra 2007). As a result, there is a need to critically explore nursing and migration (both international and internal) in the Indian context and assess how it extends theoretical debates regarding nursing and its place in the GCC.

While much of the focus on females and migration in Kerala has been linked to women being left behind by male migrants (Gulati 1996; Sekhar 1996), a growing body of literature has 
explored the migration of female nurses from Kerala to the USA (George 2005), Australia and UK (Healey 2006) and the Gulf Region (Percot 2007; Percot and Rajan 2007). Although the 2007 Kerala migration survey indicated stasis in terms of emigration numbers from Kerala overall, and a decline in the percentage share of female immigrants from 16.8 per cent in 2003 to 14.4 per cent (Zachariah and Rajan 2007), female migration continues to be of importance. The majority of female migrants from Kerala tend to be skilled nurses, and researchers estimate that 90 per cent of migrant nurses both across India and in the Gulf are from Kerala (Nair and Percot 2007). While the presence of skilled female migrants from the state supports the popular argument that Kerala has a greater degree of gender empowerment (Sen 1997), this aspect of the 'Kerala model' of development has been seriously questioned of late in light of disturbing indicators such as the rise in dowry and gender based violence (Eapen and Kodoth 2002; Rajan and Sreerupa 2007). Saradamoni (1994) argues that rather than representing a new model of development, Kerala has uncritically internalized other development models including excess consumerism and individualism, which drives and is driven by wealth from international migration, and undermines more collectivist approaches to social organization, all of which diminish women's resources and support structures (see also Kurien 2002). Overall then the issue of nurse emigration from India provides an important optic into issues of gender, migration and development.

\section{Gender, migration and the status of nursing in India}

Survey and interview data from students and faculty at three Government Colleges, six private Colleges and one private nursing school in south and central Kerala was collected in late 2008 with the aim of assessing the culturally embedded specifics of changing occupational status for nurses in light of increasing international nurse migration opportunities. Over 1,100 students were surveyed on their intentions to migrate, and a minimum of three interviews/focus groups were conducted with faculty and students per college, including questions about marriage issues, nursing status and overseas opportunities (Walton-Roberts 2010). Permission to interview at various colleges was secured via the appropriate hospital directors, and government departments, and the researcher and local research assistant arranged meeting times and visited each educational institution (and often the hospitals connected to them). In addition, five interviews 
were conducted with officials in the department of medical education (nursing) and in private and government recruitment agencies. Interviews with nursing students were conducted in Malayalam, the local language, by the project's research assistant; all others were conducted in English by the author. Interviews were recorded and transcribed where permission was granted, and analyzed for various themes using Nvivo qualitative data analysis software. This paper highlights the themes of nursing status and how migration informs the marriage market.

\section{The development of the nursing profession in India}

In Kerala the Christian community's traditional dominance of nursing occurred because Christianity was supposedly outside of Hindu caste restrictions, but Christian communities were seen as low caste converts, and thus the nursing profession was still historically constructed in low caste terms (Jeffery 1988; Raghavachari 1990). Understanding this history of stigma and low status attached to nursing in India necessitates some understanding of the role played by religious orders and colonial hierarchy, which has arguably created a heavily feminized and subservient frame of reference for nursing, which continues into the present. Basuray (1997:17) argues that 'the underlying message in the practice of nursing care in colonial India was the total superiority of the western health care system and science over that of the native culture's concepts and practices and health care'. Basuray also suggests that this model of nursing eventually resulted in the oppressed becoming the oppressors as Indian nurses who trained under this system internationalized the notion of superiority over the native. Thus status and subservience became entrenched within the medical system, and since nurses already held a tenuous position in the hierarchy of power, they actively sought status distinctions against patients and their families, orderlies, and junior nurses.

Research on changes in Indian nurse training and practice in the immediate post-colonial era also highlight how the social and professional status of nursing continued to be an issue of concern (Sinha 2007; Nair and Healey 2006). The impact of British colonialism and immediate post-independence western aid also structured a nursing education system that oriented training toward a western model of care. Not only did post-independence western advisors set India on the path to a professionalized (perhaps inappropriate) model of nurse training (Healey 2008), but British imperialism more generally created an infrastructure that both facilitated international 
nurse migration, while simultaneously devaluing the professional status of Indian trained nurses. For example, Solano and Rafferty (2007) detail how the British created the Colonial Nursing Service (CNS) as a way to organize British nursing appointments throughout the Empire. The colonial nursing placement system associated certain forms of identity with nursing, including the Nightingalesque qualities of 'lady' nurses. British nurses were training indigenous nurses in the colonies and thus reproducing the culture and perspective of British nurses, as Basuray (1997) also reveals. This colonial market was set up to direct British nurses to various parts of the Empire, but its orientation shifted in the post Second World War period as the needs of the NHS exceeded the UK's domestic supply of nurses. To satisfy the UK's labour demand, while also maintaining the distinction between foreign and British trained nurses, the 1943 Nurses' Act created the position of the nurse assistant, who was expected to perform less intellectually challenging nursing tasks. Thus the act:

instilled the professional hierarchy that was to favor British registered nurses, but it also impacted on professional culture, reinforcing assumptions based on race, class and social background ... It also replicated the power relations that the CNS (Colonial Nursing Service) had established in the colonies; British-born nurses dominated nursing leadership and education. (Solano and Rafferty 2007:1059).

Colonialism, therefore, created and reinforced a relationship of inequality both at home and overseas within the Indian nursing profession. This relationship extended into the post-colonial period in the development of a nursing education model that was inappropriate to India's public health needs, and in the subjugation of Indian trained immigrant nurses who entered the British health system in the post-independence period.

Colonial, post-colonial and contemporary reflections on nursing in India have all highlighted the low status attached to nursing (Abraham 2004; Arnold 1994; Basuray 1997; George 2005; Jeffery 1988; Nair and Healey 2006). In 1990 the Indian Central government formed the Sarojini Varadappan committee to examine nursing and the nursing profession. The committee's report cited a number of challenges including: a lack of nurses, a curative model of health, the practice of depending on student labour, shortages of nurses in hospitals, schools being poorly resourced with a lack of necessary equipment and infrastructure, and poor pay and 
conditions. The report also noted the severe lack of autonomy and respect the nursing profession received, and commented that physicians usually made decisions and gave directions with regard to nurses and nursing care. This was followed in 1991 by the formation of a working group on education and manpower, and as a consequence of both of these, continuing and higher level nurse education was encouraged, and included the creation of a $\mathrm{PhD}$ programme, a focus on higher level education for teachers, changes to the BSc programme, and the suggestion to phase out the General diploma by 2020. ${ }^{1}$ By the mid 2000s India was still struggling with the supply and status of nursing; while 900,000 nurses were registered with various state councils only 40 per cent of these were in active duty (Sinha 2007). And although India has the capacity to train over 100,000 nurses a year in various programmes, it is estimated that at least 20 per cent of these emigrate annually (Sinha, 2007). Recent state efforts have focused on improving the status of nursing through curriculum reform, and the Central Health Ministry has dedicated funds ( $₹$ 319 Crore or approximately US\$70 million) in the $11^{\text {th }}$ plan to strengthen nursing education, since it is arguably still not seen as a popular option by many students (Sinha 2007). Recent Indian Nursing Council changes have also eased student entry criteria and relaxed the regulations new nursing programs must meet in order to become accredited. ${ }^{2}$ Such changes were greeted positively by the private sector, but not by nursing groups and some state governments (Times of India 2008). ${ }^{3}$ Despite these ongoing changes, nursing in India still struggles to overcome its poorer sibling standing in the medical hierarchy: 'Nursing appears to be understood as the lesser of the professions in comparison to medicine and this hierarchy is practically upheld in the hospitals' (Nair and Healey 2006:16).

The status of nursing in India must be considered in any assessment of the nation's role in the GNCC, because relative devaluation of the profession acts as a prime migration push factor. In most interviews with nursing students one of the most persistent reasons cited to explain their interest in overseas migration was their perception of the greater respect nurses garnered overseas for both their occupation and education:

Female 2: In Kerala [you are] 'just nurse' and we do not have good salary, but overseas we get high salary and respect for nurses, that's why we like to go abroad. 
Female 1: We're doing more service and work than doctors, but nurses still do not get good status. (Interview with College of Nursing student, Kollam, October $18^{\text {th }} 2008$, transcribed from Malayalam)

Female 3: Bachelor of Nursing has good knowledge about all kind of medical diseases but society does not realise very well yet. They still think nurses means just nurses.

Male 1: Even when we have post graduation in nursing we do not get good status in

Kerala and India, that is one fact why we are looking to go abroad.

(Interview with 3rd year students, Kottayam Nursing College, 20 October 2008, translated from Malayalam by Jithin Raj).

It is clear that these students are invested in improving the hierarchy and status embedded within the nursing profession, and they see their best prospects explicitly located within a global labour market. The status of nursing is not just about income earning potential and job satisfaction though, but also has an important bearing on matrimonial options.

\section{The improving status of nursing and its impact on marriage}

Migration has a profound impact on gender relations in terms of marriage, as Xiang (2005) has shown in the case of Indian male migrants in the IT sector. The marriage market is a mechanism for recognizing relative status, and while migration and the economic wealth it generates can have a positive impact on status, such status can also be culturally devalued within the matrimonial market. Scholars have argued that, in addition to religion and status, caste is a powerful matrimonial organizing factor in Kerala; and status can be powerfully informed by migration (Kurien 2002). Saradamoni (1994) argues that in Kerala the internalization of consumerism and individualism, which is driven by and drives international migration, has contributed to the increasing problem of large wedding dowries that have become increasingly common among all religious and class groups in Kerala, despite the financial distress it causes for middle- and lower-class families alike. The dowry process is also evident in the postmigration context, as Gallo $(2005,2006)$ reports in the case of female Malayali (Kerala) migrants in Italy, who take an active pride in their ability to offer substantial dowries for their own and 
other female relatives' weddings. Thus, rather than challenge patriarchy, female migration can actually perpetuate elements of it.

In terms of the wider status of nursing and how this impacts matrimonial options, George (2005) notes the challenges some Christian nurses in the USA faced in finding suitable matches for their children, in part because of the negative view associated with their occupation and mobility. Contrasting this view, Percot (2007) argues that in Kerala nursing it is no longer seen in the negative light it once was; she argues nurses do not have to pay large dowries, and are sought out in the marriage marketplace. In my interviews with nursing students and faculty the issue of nurses' marriage prospects received mixed responses. While most agreed that the 'pollution' stigma associated with nursing has disappeared - and nurses are now seen as popular marriage matches for those who wanted to go, or were already, overseas - many did agreed that nurses were still not attractive to higher class and caste groups.

One measure of the improving status of nursing can be measured in the profession's attractiveness beyond the traditional Christian community (Percot 2007), and my survey results support the observation that other religious groups are entering the profession. Hindu students made up 37 per cent of the total sample of nursing students, Christian students 53 per cent, and Muslim students were also evident at 8 per cent. Male students also represented 16 per cent of the total sample, but almost a third in government colleges (see Table 1).

\section{Insert Table 1 about here}

The legacy of Christian involvement in nursing was still clearly evident in the reproduction of the nursing vocation through the 'nurse relative' question, in that three quarters of Christian students had a family member who was a nurse compared to only one third of Muslims, and just over 40 per cent of Hindus. With reference to marital status, across all religions over 90 per cent of students were single, and this reflects the relatively young age of students (average age was 20 years), and probably the traditional limitations placed on nursing students, in that until the mid 2000s regulations prohibited marriage while enrolled in nursing college. With regard to the engagement of nurses, it is not obvious from this research that 'Girls with a good family background are in such demand that they get "booked up" while still in 
school' (George 2000: 152 cited by Percot and Rajan 2007; 321). Instead what is evident is the overwhelming tendency of all religious groups to be single during their education (a greater tendency to be engaged does exist for Muslim students, yet this is still minor). Marital commitment is not necessarily part of the nursing education phase for most religious groups in Kerala, and instead arises later when students have gained employment. This was also suggested in interviews with faulty, where marriage markets for nurses included what could be seen as a segmented market inhabited by those planning to go, or were already based, overseas.

Question: For a typical graduate... when are they going to look into the matrimonial market?

Female 1: After they graduate college [while they are working in India].

Question: Is there a good marriage market for nurses?

Female 1: [Laughter] there is, all are looking for nurses,

Female 2: Good market [for people working overseas] they are all looking to marry nurses.

Question: Who will be looking for a nurse?

Female 1: Mostly professional men for working outside...engineers.

(Focus group with faculty, nursing college, Trivandrum, 13 November 2008).

The diversification in the gender and religious background of nursing students is certainly indicative of the improving status of the profession. This is also evident with regard to nurses' position in the matrimonial market, but the perception of status and dowry expectations is still mixed. In a focus group with nursing students in central Kerala, when asked if nurses are seen as a good marriage prospect, all the students agreed they were due to earnings and the potential to secure an overseas visa, but in regards to dowry, the group expressed some disagreement:

Male 1: In my opinion if I marry a BSc nurse I do not [receive] dowry because I know she can earn.

Female 1: I do not agree $100 \%$ because even BSc nurses they are asked for dowry ... depends on the person (other female students also agree). (Interview with nursing students, Kollam, 18 October 2008, translated from Malayalam). 
Question: Are nurses seen as a good marriage prospect?

Female 1: yes because of the earning potential .They know nurses get good salary.

Question : what about dowry, do you think nurses do not have to pay huge dowry?

Female 2: people saying that, but I do not think that is true.

(Other students also agree).

(Interview with third-year students in Kollam nursing college, 13 October, transcribed from Malayalam).

The value of a nursing qualification and the potential migration opportunities it presents can widen marital options, and as such becomes important to consider within the GNCC model. Understanding the matrimonial market is a key indicator of how the status of nursing is transforming alongside wider transformations in gender relations and the expansion in overseas opportunities for nurses. It also indicates the importance of widening the focus of GNCC research beyond the state and workplace setting in order to incorporate community processes that alter the relative value of occupational status. In the case of Kerala this raises the question of how gendered migration intersects with society's traditional sexual norms and conventions.

\section{Sexualizing impurity at home and away: Binding the identity of skilled and unskilled female migrants}

Rather than powerfully articulated with modernity and development, as male migrants have been constructed (Varghese 2006), Kerala's female migrants are still subjected to deeply embedded negative constructions. Such perceptions include assumptions that single women who go overseas and earn a good wage are 'loose women' or 'suspicious'. Such concerns are heightened in cases where women are single and abroad, since any abuse of the female outside of the nation is also read as a violation of the 'symbolic property of the nation' (Oishi 2005: 100). This is one means by which skilled and unskilled female migrants are bound together. The contribution of Indian female migrants to India's development tends to be muted, or cast as a problem that that state needs to manage. For example, in a recent edited volume on India's relations with West Asia, of only two chapters on the Indian diaspora, the first lacked any discussion of female migrants (Jain 2008), and the second briefly mentions female migration, but only as an unskilled group whose vulnerabilities creates problems for the Indian Government, who 'should devise 
some measures to protect them from this kind of humiliation' (Rahman 2008: 220). In an interview with a government recruitment agent in Kerala, the reluctance to place women overseas as domestics was clearly linked to concern with these issues:

Question: But your preference is no domestic appointments?

Answer: Yes because that is a risk, I am not prepared to do anything that will demean the name of organization. That may be why the government institutions get lesser numbers of people ... because they [private agencies] are ready to take the bad jobs.

Question: Are there other countries that send domestics?

Answer: I see countries like Philippines, some of the eastern countries, but I think young ladies are also bold enough to manage that. One should be bold. But if you happen to be in the house, it will be difficult for you, if you get in trouble. ... you cannot get out, you cannot fly home as you wish, you have to get the ticket, you have to think twice about your dependents. Those things are there.

Question: You don't think Indian women or women from Kerala are really suited [to domestic work]?

Answer: No ... we stand on a higher plane morally. Moral standards or name or expectations of Indian women are higher. We value that very much.

(Interview in Government placement agency, Trivandrum, Kerala, October $6^{\text {th }} 2008$ )

Even private recruiters who are often portrayed as rapacious and uncontrolled in their attempts to service overseas demands for labour are reluctant to enter this growing feminized care sector:

Male 1: a lot of problems are there [Indian female workers in the Gulf]. You see Indian women are very, totally afraid kind of human being, in all of the world. That is the thing. They are very much attached to their traditions, religion. Some women are very capable to make money, they can do anything they can work anywhere by any means. So that does not fit ... with Kerala traditions.....

Question: You don't want to do that? [place women in United Arab Emirates] Women are seen as too free in Dubai?

Male 2: Not just Dubai but people from Kerala in Bangalore, Delhi. 
Male 1: Anywhere.

Question: So any female migrants are seen as suspicious?

Male 1: Yeah, especially from India

(Interview with private recruitment labour agents, Varkala, Kerala September $15^{\text {th }} 2008$ )

This view circulates the common discourse of migrant women as victimized workers whose problems stem from their embodied female weakness, rather than from weak regulatory protection in the host state. It is also suggestive of a view of female sexuality that is something that must be controlled through strict social norms exercised within in a spatially contained context. The Indian government heeds this popular sense of concern, which results in policies that control the mobility of unskilled women under thirty-five years old, who are not permitted to take up work overseas without proper papers. These restrictions are maintained despite pressure from some receiving states in the Gulf to relax the regulations (personal interview with Kerala government NORKA official, Kerala, October 2008). In an interview with an embassy official in Dubai, the legislation limiting the migration of female domestic workers under 35 years old was defended:

There has been a lot of abuse of housemaids. In a democratic society people in India do not like to hear or read or see that women go out and they are abused...but still the dominant sentiment is ... we do not care if people lose jobs and do not go out, if even a small number come out and are abused. (Indian Consulate, Dubai, November 19 2008 ).

Placement agencies, both public and private, and government agents facilitate international migration, and play a part in this process of inscribing and regulating gendered migration, and reinforce elements of spatial control. There is certainly a spatial politics to this sense of outrage, since the Indian state itself is reluctant to include domestic space in national workplace sexual harassment legislation currently under consideration (Sharma 2011). Indian national sensitivity to the symbolic gender politics of migration and women's work is then clearly differentiated, legislatively, discursively and spatially; if it is 'over there' male officials can take the moral high ground by limiting women's opportunities because of concerns over their exploitation, but if it is 'over here' in India, it can be ignored. 
In the case of nursing, concerns over sexual and other exploitation are allayed somewhat by the formality of the institutional setting. Thus the institutional dimensions of the GNCC compensate for the otherwise restrictive view of female migration, and opens up important sanctioned channels for the migration of women from India:

Question: So they can work abroad as single women overseas in hospitals, the hospitals look after them?

Answer: Yes the government/hospitals look after them... and you know we make sure of that. (Government placement agency, Trivandrum, Kerala, October $6^{\text {th }} 2008$ )

However, even single women who migrate within this occupationally protected channel are still perceived with some sense of suspicion, illustrating Choy's (2003) point about the binding together of skilled and unskilled female migrant identities, and also highlighting the continued challenges nurses face in terms of their status. As Abraham (2004: 9) states:

the sexual insecurity, which nurses face, both within health care institutions and outside, is widespread and highlighted in popular literature and cinema, but is hardly explored as a social problem. Thus, it is found that through women's education and salaried employment are two important and necessary tools for them to acquire status, power, and autonomy, but they are not sufficient elements.

In Kerala the recent increase in female skilled migration through nursing and its associated mobility, freedom and independence, is seen to escape the moral policing normally exercised within the state. This raises issues of 'nanam', or shame as Osella and Osella (2008: 158) discuss: 'Hindus and Muslims alike accuse Christians of putting money above all and of caring nothing for reputation, by "sending their women to work as nurses to Arabs", at times going as far as openly suggesting a direct relationship between nursing and prostitution.' Migrant women regardless of occupation are thus constructed as contravening certain morals and taboos, and this emerges in relation to international and internal migration. To illustrate this I quote from an interview with nursing students in south Kerala: 
Question: Do you worry yourself about 'suspicious' issue? Because I have one friend in Bangalore she is a nurse and she one day told me 'Oh ... maybe you and local people [her neighbours etc..] thinking I "put out" or "I am wrong", which means she worrying herself about suspicious issue.

Female 1: if women are working in Bangalore, our local people looking suspiciously [at] her because of her being in Bangalore.

Male 1: lots of bad things happened in Bangalore, which means the nursing student from Kerala they are modern in Bangalore more than they were in Kerala...if we go to work in Bangalore it's okay when we go with professional degree, which means less chance to [been seen as] suspicious if we have good hospital job there. (Interview with nursing college students, Varkala, September $3^{\text {rd }} 2008$, translated from Malayalam).

Similar gendered spatial regulation debates emerge in cyber space, where women's mobility, both international and domestic, is coupled with sexually liberated (read deviant) behavior that contradicts the Kerala moral standard. The accusation of sexual impurity, a powerful form of social control, is deployed to deny migrant nurses social mobility, and ultimately damages their potential marriage prospects:

Guys who are going to marry girls from INDIA beware of girls who studied nursing or other subjects especially in Banglore. Banglore is like a Veeshikal [prostitute] central for girls from kerala. 95\% of the girls who work there or study there have multiple sexual partners. They have many boy friends. They say they are studying nursing or working there but they are actually doing all this stuff very openly. ... they are worse then the women from USA. Many of them are BSC nurses!” (sic) (Posted 27 January 2007, Kerala Café internet chat site). ${ }^{4}$

Further comments posted on the same website note similar concern regarding the sexuality of nursing students and concern regarding their exposure to male sexual organs before marriage, ${ }^{5}$ and suggestions that families deliberately profit from sending their females relatives overseas. Such vehement blogs can be dismissed as gross misrepresentations, but concern about such stigmatization of migrant nurses was an important motif in discussions with nursing students and 
faculty in Kerala. In one large focus group interview with a number of government college nursing faculty, concluded with general agreement that status was still a concern:

Female 2: In the old days that was there [stigma]

[General disagreement within the faculty and some discussion]

Female 1: It is decreasing...

Question: Are nurses attractive matches for doctors?

Female 1: No, not in Kerala

Question: So there is still a stigma?

Female 1: Only in Kerala.

(Focus group with faculty, Government College of Nursing, Trivandrum, Kerala, November $13^{\text {th }}$ 2008).

In Kerala, when compared to the male migrant, female migrants' identities can be devalued because of their mobility, but this process of devaluation is mediated and subject to transformation over time. Even as the nursing profession has transformed, the residue of impurity remains, and the economic benefits of migration are socially devaluation through the moniker of sexual impropriety. The independence of female nurses, working with men, sometimes at night, and the mobility nurses experience has challenged the gender norms of south Indian society. In response to these transgressions, the idea of the nurse as a 'suspicious' figure gains salience, and is used to challenge the class mobility female nurses may experience through the migration process. Thus her symbolic and cultural capital is undermined even as her economic capital improves, and sexual impurity is one of the most powerful discourses of disempowerment female nurses have faced (Abraham 2004).

This research suggests that as caste-based taboo stigmas have subsided, a discourse of gender-based impurity informed by migration and undisciplined sexuality has taken its place. This transposition effectively illustrates the point Meillassoux (1973: 107) makes about impurity being used as a flexible tool of oppression:

the symbolic criteria of impurity were not congruent with the class hierarchy ... In reality, impurity was one more weapon in the repressive ideological arsenal used in one 
direction only, arbitrarily and opportunistically as a means of discrimination, oppression and exploitation, but with no logical coherence even of a 'structuralist' kind.

\section{Conclusion}

The GNCC, with its sensitivity to the underlying discourses of feminized migration and care decisions, provides an appropriate lens to examine India's growing export of nurses. In order for the GNCC to maintain its strong feminist politicization, the micro scale of social reproduction, sexuality and matrimonial markets must be assessed (see also Andrijasevic, 2009). In this way the GNCC will be explicitly politicized to assess the particularities of gendered migration and the feminization of international health care services, and its relationship to continued forms of global inequality across different contexts. As the international demand for this sector of health worker continues to increase (Brush 2008), and as India's nurse training model resumes its western focus through curriculum reform and professionalization, the global migration of nurses will remain of importance to India's economic, social and cultural development, despite temporary variations in international demand.

For Kerala in particular, the migrant figure embodies a powerful influence that needs to be understood as the outcome of specific sets of relations including global, regional and national discourses of modernity, development, neoliberalism and patriarchy. As the potential for India to service the GNCC increases, state and society perceptions of female migration will alter, and how this structural international labour circulation is rescaled to the level of the household and community, and vice versa, is key to determining how the benefits and costs of this process will be shared. What is already evident is that processes of social mobility are highly complex, and skilled migration from Kerala offers substantial social mobility for men and women; but this is also associated with the fragility of identity when women are subjected to discursive devaluing across the migratory landscape, as this research and others reveals (Abraham 2004; George 2005; Nair 2007). Though there are clearly emancipatory aspects of nurse migration (Percot 2007), the resilience of the sexualized, as opposed to polluting, stigma associated with nursing and with migration (both international and internal) for women must be accounted for in assessments of India's growing role in the GNCC. Simple assumptions that skilled migration equates with improved status and emancipation for women are misplaced. The discursive context of impurity 
linked to sexual behavior is used to undermine the social mobility female nurses gain through migration, and charting its presence and influence provides a window onto the rapid changes occurring within Indian society as female migration is increasingly facilitated by the twinned processes of the state's response to the global demand for nurses, and Indian society's desire for social mobility. This analysis also contributes to the discussion of transnational mobilities of care by highlighting how care and care-giving is an embodied act reflecting intersections of identity and place, thereby adding complexity to our understanding of carework as a cultural and highly spatialized experience.

The gendered dimensions of nurse migration from Kerala also raise important questions about the 'Kerala model' of development, which supposedly incorporates a high degree of female empowerment. Despite the ongoing expansion of nursing education and greater diversity in the gender and religious background of nursing students, poor status is still a concern. It can be seen in the discourses of sexual stigma that affect matrimonial processes. How this is experienced by male nurses is an important question for future research. In the current context, the issue of care has become a heavily gendered element of the global economy that is deeply cultural embedded and produced through place-specific social relations that are increasingly intersecting with transnational labour migration circuits. Monitoring how these intersections inform and reshape each other is a strength the GNCC can offer as a conceptual framework. How female migration and mobility is interpreted within Kerala provides a lens onto the changing status of gender relations and the perception of gender empowerment within the state, and indeed the nation. Critically assessing the connections between the various scales involved in this process is a demanding yet promising research agenda to pursue.

\section{Acknowledgements}

Research for this project was funded by Shastri Indo Canadian Institute and Wilfrid Laurier University (WLU). Ethics approval was applied for and granted through WLU, and visiting scholar affiliation with the Center for Development Studies (CDS), Thiruvananthapuram, Kerala also contributed importantly to the validity of the research project and facilitated access to 
Government Nursing Colleges. I also thank Jithin Raj for his research assistance in Kerala, and the valuable comments of three anonymous reviewers of earlier drafts of this paper.

\section{Notes}

1. http://nursingplanet.com/nr/blog6.php/2009/11/23/development-of-nursing-education-inindia-post-indpendence accessed 21 March 2010.

2. http://www.indiannursingcouncil.org/pdf/New-Admission-Eligibility-Criteriarelaxed.pdf, accessed 28 April 2009.

3. Also see http://www.collegesintamilnadu.com/Education_News/20091/20090126e.asp, accessed 8 May 2009.

4. http://www.keralacafe.com/cgi-bin/forum/Blah.pl?b-3/m-1170216697/, accessed 9 May 2009.

5. http://www.keralacafe.com/cgi-bin/forum/Blah.pl?b-3/m-1170216697/, accessed 24

February 2011

\section{References}

Abraham, B. (2004) 'Women nurses and the notion of their "empowerment", Discussion Paper No. 88 Kerala Research Programme on Local Level Development, Centre for Development Studies, Thiruvananthapuram.

Al-Jarallah, K.F., M. A. Moussa, S. K. Hakeem, and F. K. Al-Khanfar. (2009) 'The nursing workforce in Kuwait to the year 2020', International Nursing Review, 56, 65-72.

Anderson, B., (2009) 'What's in a name? Immigration controls and subjectivities: The case of au pairs and domestic worker visa holders in the UK.' Subjectivity 29: 407-424

Andrijasevic, R., (2009) "Sex on the move: Gender, subjectivity and differential inclusion." Subjectivity 29, 389-406.

Arnold, D., (1994) 'Crisis and contradiction in India's public health', in D. Porter (ed.) The history of public health and the modern state, Amsterdam: Clio Medica, 335-55. 
Basuray, J., (1997) Nurse Miss Sahib: colonial culture-bound education in India and transcultural nursing', Transcultural Nursing, 9, 14-19

Brush, B. L. and J. Sochalski (2007) 'International nurse migration: lessons from the Philippines', Policy, Politics and Nursing Practice, 8(1), 37-46

Brush, B. (2008) 'Global nurse migration today', Journal of Nursing Scholarship, 40(1), 20-25.

Cheng, S-J. A. (2004) 'Contextual politics of difference in transnational care: the rhetoric of Filipina domestics' employers in Taiwan', Feminist Review, 77, 46-64.

Choy, C.C. (2003) Empire of care: nursing and migration in Filipino American history, Duke University Press: Durham and London.

Connell, J. (ed.) (2008) The international migration of health workers: a global health system?, New York: Routledge

Dyer, S., L. McDowell, and A. Batnitzky (2008) 'Emotional labour/body work: The caring labours of migrants in the UK's National Health Service', Geoforum, 39, 2030-38.

Dicicco-Bloom, B. (2004) 'The racial and gendered experiences of immigrant nurses from Kerala, India', Journal of Transcultural Nursing, 15(1), 26-33.

Eapen, M., and Kodoth. P., (2002) Family structure, women's education and work: reexamining the high status of women in Kerala, CDS Working Paper No.341, Trivandrum: Centre for Development Studies (CDS).

Ehrenreich, B. and A. R. Hochschild (eds) (2002) Global woman: nannies, maids and sex workers in the new economy, New York: Metropolitan Books.

Folbre, N. (2005) 'Nursebots to the rescue? immigration, automation, and care', Globalizations, 3(3), 349-60

Gallo, E. (2005) 'Unorthodox sisters: gender relations and generational change among Malayali migrants in Italy', Indian Journal of Gender Studies, 12, 217-51.

Gallo, E. (2006) 'Italy is not a good place for men: narratives of places, marriage and masculinity among Malayali migrants', Global Networks, 6(4), 357-72.

George, S. (2005) When women come first: gender and class in transnational migration, Berkeley, CA: University of California Press.

Gordon, S. (2005) Nursing against the odds, Ithaca: Cornell University Press 
Goss, J. and B. Lindquist (1995) 'Conceptualizing international labour migration: A structuration persepective', International Migration Review, 29(2), 317-51.

Gulati, L. (1996) In the absence of their men: the impact of male migration on women, New Delhi: Sage Publications.

Hadley, M. B., L. S. Blum, S. Mujaddid, S. Parveen, S. Nuremowla, M. E. Haque, and M. Ullah (2007) 'Why Bangladeshi nurses avoid "nursing": social and structural factors on hospital wards in Bangladesh', Social Science and Medicine, 64, 1166-77.

Hadley, M. B. and M. Roques (2007) 'Nursing in Bangladesh: rhetoric and reality', Social Science and Medicine, 64, 1153-65

Healey, M. (2006) 'Outsourcing care: ethics and consequences of the global trade in Indian nurses', www.sueztosuva.org.au/south_asia/2006/Healey.pdf, retrieved 2 October 2008.

Healey, M. (2008) 'Seeds that may have been planted may take root: international aid nurses and projects of professionalism in post-independence India, 1947-1965', Nursing History Review, 16: $58-90$

Hochschild, A. R. (2001) 'Global care chains and emotional surplus value', in W. Hutton and A. Giddens (eds) On the edge: living with global capitalism, London: Vintage, 130-46.

Jain, P. K. (2008) 'Indian diaspora in West Asia' in R. M. Abhyankar (ed.) West Asia and the region: defining India's role, New Delhi: Academic Foundation, 177-202

Jeffery, R. (1988) The politics of health in India, Berkeley: University of California Press.

Kalita, P. (2003) 'Nursing system in poor health', Times of India, 9 September.

Kelly, P. F. and S. D. Addario (2008) “"Filipinos are very strongly into medical stuff”: labour market segmentation in Toronto, Canada.' In J. Connell (ed.) The international migration of health workers, London: Routledge,77-98.

Khadria, B. (2007) 'International nurse recruitment in India', Health Research and Educational Trust, 42, 3 Part II, June, 1429-36.

Kingma, M. (2006) Nurses on the move: migration and the global health care economy, Ithaca and London: Cornell University Press.

Kurien, P. (2002) Kaleidoscopic ethnicity: international migration and the reconstruction of community identities in India, New Brunswick: Rutgers University Press

Meillassoux, C. (1973) 'Are there castes in India?', Economy and Society, 2, 89-111. 
Nair, S. (2007) 'Rethinking citizenship, community and rights: the case of nurses from Kerala in Delhi', Indian Journal of Gender Studies, 14(1), 137-56.

Nair, S. and M. Healey (2006) 'A profession on the margins: status issues in Indian nursing', Centre for Women's Development Studies, New Delhi, Occasional Paper series.

Nair, S. and M. Percot (2007) 'Transcending boundaries: Indian nurses in internal and international migration', Occasional Paper, Centre for Women's Development Studies, http://www.cwds.ac.in/occasionalpapers.htm, accessed January 2009.

Oishi, N. (2005) Women in motion: globalization, state policies, and labour migration in Asia, Stanford, California: Stanford University Press

Osella, C. and F. Osella (2008) 'Nuancing the migrant experience: perspectives from Kerala, South India', in S. Koshy and R. Radhakrishnan (eds) Transnational South Asians: the making of a neo-diaspora, India: Oxford University Press, 146-78.

Parreñas, R. (2009) 'Closing remarks', Transnational Mobilities for Care Conference, National University of Singapore, 10-11 September.

Percot, M. S., (2007) 'Indian nurses in the Gulf: two generations of female migration', South Asia Research; 26, 41-62.

Percot, M. S. and I. Rajan (2007) 'Female emigration from India: case study of nurses', Economic and Political Weekly, 42, 318-25.

Pratt, G. (1999) 'From registered nurse to registered nanny: discursive geographies of Filipina domestic workers in Vancouver, B.C', Economic Geography, 75(3), 215-36

Rahman, A. (2008) "Indian Manpower in the Gulf: Strategic and Economic Dimensions" in West Asia and the Region: Defining India's Role. Edited by R.M. Abhyankar. Academic Foundation: New Delhi 203-224.

Raghavachari, R. (1990) Conflicts and adjustments: Indian nurses in an urban milieu, Academic Foundation: New Delhi

Rajan, S. I. and Sreerupa (2007) 'Gender disparity in Kerala: a critical reinterpretation', in S. Mukhopadhyay (ed.) The enigma of the Kerala women: a failed promise of literacy, New Delhi: Social Science Press, 32:70.

Rajan, S. I., and U. S. Mishra (2007) 'Managing migration in the Philippines: lessons for India', Centre for Development Studies, Trivandrum, working paper No. 393. 
Salvage, J. (1985) The Politics of nursing, London: William Heinemann

Saradamoni, K. (1994) 'Kerala and some development issues', Economic and Political Weekly, 29(9), 501-509

Sekhar, T. V. (1996) 'Male emigration and changes in the family: Impact on female sex roles', Indian Journal of Social Work, 57(2), 277-94.

Sen, A. (1997) 'Population policy: authoritarianism versus cooperation', Journal of Population Economics, 10(3), 3-22.

Sharma, B. (2011) 'India overlooks abuse of domestic workers in new sexual harassment bill', Christian Science Monitor, 23 February.

Shukla, S. (2009) 'HIV stigma plagues nurses in developing countries', University of California San Francisco today, 22 January, http://today.ucsf.edu/stories/hiv-stigma-plagues-nurses-indeveloping-countries/, accessed 15 April 2009

Sinha, K. (2007) 'Nurses' exodus leaves India short', Times of India, 12 September.

Smith, P. and M. Mackintosh (2007) 'Profession, market and class: nurse migration and the remaking of division and disadvantage', Journal of Clinical Nursing, 16, 2213-20.

Solano, D. and A. Rafferty (2007) 'Can lessons be learned from history? The origins of the British imperial nurse labour market: a discussion paper', Nursing Studies, 44, 1055-1063

Somjee, G. (1991) 'Social change in the nursing profession in India', in P. Holden and J. Littlewood (eds) Anthropology and nursing, London: Routledge, 31-56

Stilwell, B., Diallo, K., Zurn, P., Poz, M.R., Adams, O., and Buchan, J. (2003) "Developing evidence-based ethical policies on the migration of health workers: conceptual and practical challenges." Human Resources for Health 2003, 1, 8: 8-20

Times of India (2008) 'Nursing institutes have a reason to cheer', 15 December, http://timesofindia.indiatimes.com/articleshow/msid-3838449,prtpage-1.cms, accessed 5 May 2009

Tschudin,V., A. J. Davis, and C. Hancock (eds) (2008) The globalisation of nursing, Abingdon, Oxon.: Radcliffe Publishing.

Van Dongen, E. and R. Elema (2001) "The art of touching: the culture of "body work" in nursing', Anthropology and Medicine, 8 (213), 149-62. 
Varghese, V. J. (2006). 'Migrant narratives: reading literary representations of Christian migration in Kerala, 1920-70', Indian Economic and Social History Review, 43(2), 227-55.

Walton-Roberts, M. (2010) 'Student nurses and their post graduation migration plans: a Kerala case study', in S. Irudaya Rajan (ed.) India migration report 2010, New Delhi: Routledgei, 196216.

Xiang, B. (2005) 'Gender, dowry and the migration system of Indian information technology professionals', Indian Journal of Gender Studies, 12(2-3), 357-80.

Yeates, N. (2004) 'Critical reflections and lines of enquiry', International Feminist Journal of Politics, 6(3), 369-91.

Yeates, N. (2009) Globalizing care economies and migrant workers: explorations in global care chains, Basingstoke, Hants.: Palgrave Macmillan

Zachariah, K. and S. Irudaya Rajan (2007) 'Migration remittances and employment: short term trends and long term implications', Working paper 395, Centre for Development Studies (CDS), Trivandrum, Kerala.

Zaman, S. (2009) 'Ladies without lamps: nurses in Bangladesh', Qualitative Health Research, 19, 366-76. 


\begin{tabular}{|c|c|c|c|c|c|c|c|c|c|}
\hline & $\begin{array}{l}\text { Total } \\
\text { sample }\end{array}$ & $\begin{array}{l}\text { Gov't } \\
\text { Colleges }\end{array}$ & $\begin{array}{l}\text { Christian } \\
\text { Colleges }\end{array}$ & $\begin{array}{l}\text { Hindu } \\
\text { Colleges }\end{array}$ & Female & Male & Christians & Hindu & Muslim \\
\hline & $n=1169$ & $n=376$ & $n=360$ & $n=433$ & $\mathrm{n}=979$ & $\mathrm{n}=190$ & $n=441$ & $n=631$ & $\mathrm{n}=95$ \\
\hline \multicolumn{10}{|l|}{$\underline{\text { Gender }}$} \\
\hline Female & $\begin{array}{l}83.7 \% \\
(979)\end{array}$ & $\begin{array}{l}67.29 \% \\
(253)\end{array}$ & $\begin{array}{l}91.39 \% \\
(329)\end{array}$ & $\begin{array}{l}91.69 \\
(397)\end{array}$ & $\begin{array}{l}100 \% \\
(979)\end{array}$ & $\begin{array}{l}0 \% \\
(0)\end{array}$ & $\begin{array}{l}83.45 \% \\
(368)\end{array}$ & $\begin{array}{l}86.69 \% \\
(547)\end{array}$ & $\begin{array}{l}66.32 \% \\
(63)\end{array}$ \\
\hline Male & $\begin{array}{l}16.3 \% \\
(190)\end{array}$ & $\begin{array}{l}32.71 \% \\
(123)\end{array}$ & $\begin{array}{l}8.61 \% \\
(31)\end{array}$ & $8.31(36)$ & $\begin{array}{l}0 \% \\
(0)\end{array}$ & $\begin{array}{l}100 \% \\
(190)\end{array}$ & $\begin{array}{l}16.55 \% \\
(73)\end{array}$ & $\begin{array}{l}13.31 \% \\
84 \%\end{array}$ & $\begin{array}{l}33.68 \% \\
(32)\end{array}$ \\
\hline \multicolumn{10}{|l|}{$\underline{\text { Religion }}$} \\
\hline Christian & $\begin{array}{l}53.9 \% \\
(631)\end{array}$ & $\begin{array}{l}47.07 \% \\
(177)\end{array}$ & $\begin{array}{l}80.56 \% \\
(290)\end{array}$ & $\begin{array}{l}3.93 \% \\
(17)\end{array}$ & $\begin{array}{l}37.59 \% \\
(368)\end{array}$ & $\begin{array}{l}38.42 \% \\
(73)\end{array}$ & $\begin{array}{l}100 \% \\
(441)\end{array}$ & $\begin{array}{l}0 \% \\
(0)\end{array}$ & $\begin{array}{l}0 \% \\
(0)\end{array}$ \\
\hline Hindu & $\begin{array}{l}37.7 \% \\
(441)\end{array}$ & $\begin{array}{l}35.64 \% \\
(134)\end{array}$ & $\begin{array}{l}16.11 \% \\
(58)\end{array}$ & $\begin{array}{l}91.69 \% \\
(397)\end{array}$ & $\begin{array}{l}55.87 \% \\
(547)\end{array}$ & $\begin{array}{l}44.21 \% \\
(84)\end{array}$ & $\begin{array}{l}0 \% \\
(0)\end{array}$ & $\begin{array}{l}100 \% \\
(631)\end{array}$ & $\begin{array}{l}0 \% \\
(0)\end{array}$ \\
\hline Muslim & $\begin{array}{l}8.12 \% \\
(95)\end{array}$ & $\begin{array}{l}16.76 \% \\
(63)\end{array}$ & $\begin{array}{l}3.61 \% \\
(13)\end{array}$ & $\begin{array}{l}4.39 \% \\
(19)\end{array}$ & $\begin{array}{l}6.44 \% \\
(63)\end{array}$ & $\begin{array}{l}16.84 \% \\
(32)\end{array}$ & $\begin{array}{l}0 \% \\
(0)\end{array}$ & $\begin{array}{l}0 \% \\
(0)\end{array}$ & $\begin{array}{l}100 \% \\
(95)\end{array}$ \\
\hline Other & $\begin{array}{l}0.17 \% \\
(2)\end{array}$ & $\begin{array}{l}0.53 \% \\
\text { (2) }\end{array}$ & $\begin{array}{l}0 \% \\
(0)\end{array}$ & $\begin{array}{l}0 \% \\
(0)\end{array}$ & $\begin{array}{l}0.10 \% \\
\text { (1) }\end{array}$ & $\begin{array}{l}0.53 \% \\
\text { (1) }\end{array}$ & $\begin{array}{l}0 \% \\
(0)\end{array}$ & $\begin{array}{l}0 \% \\
(0)\end{array}$ & $\begin{array}{l}0 \% \\
(0)\end{array}$ \\
\hline $\begin{array}{l}\text { Marital } \\
\underline{\text { Status }}\end{array}$ & & & & & & & & & \\
\hline Single & $\begin{array}{l}98.5 \% \\
(1151)\end{array}$ & $\begin{array}{l}97.61 \% \\
(367)\end{array}$ & $\begin{array}{l}97.50 \% \\
(351)\end{array}$ & $\begin{array}{l}100 \% \\
(433)\end{array}$ & $\begin{array}{l}98.98 \% \\
(969)\end{array}$ & $\begin{array}{l}97.37 \% \\
(185)\end{array}$ & $\begin{array}{l}98.64 \% \\
(435)\end{array}$ & $\begin{array}{l}99.37 \% \\
(627)\end{array}$ & $\begin{array}{l}94.74 \% \\
(90)\end{array}$ \\
\hline Engaged & $\begin{array}{l}1.2 \% \\
(14)\end{array}$ & $\begin{array}{l}2.39 \% \\
(9)\end{array}$ & $\begin{array}{l}1.39 \% \\
(5)\end{array}$ & $\begin{array}{l}0 \% \\
(0)\end{array}$ & $\begin{array}{l}0.72 \% \\
\text { (7) }\end{array}$ & $\begin{array}{l}2.63 \% \\
\text { (5) }\end{array}$ & $\begin{array}{l}0.68 \% \\
\text { (3) }\end{array}$ & $\begin{array}{l}0.63 \% \\
\text { (4) }\end{array}$ & $\begin{array}{l}5.26 \% \\
(5)\end{array}$ \\
\hline Married & $\begin{array}{l}0.26 \% \\
\text { (3) }\end{array}$ & $\begin{array}{l}0 \% \\
(0)\end{array}$ & $\begin{array}{l}0.83 \% \\
\text { (3) }\end{array}$ & $\begin{array}{l}0 \% \\
(0)\end{array}$ & $\begin{array}{l}0.31 \% \\
\text { (3) }\end{array}$ & $\begin{array}{l}0 \% \\
(0)\end{array}$ & $\begin{array}{l}0.68 \% \\
\text { (3) }\end{array}$ & $\begin{array}{l}0.0 \% \\
(0)\end{array}$ & $\begin{array}{l}0.0 \% \\
(0)\end{array}$ \\
\hline $\begin{array}{l}\text { Nurse } \\
\underline{\text { Relatives }}\end{array}$ & & & & & & & & & \\
\hline Yes & $\begin{array}{l}52.7 \% \\
(17)\end{array}$ & $\begin{array}{l}51.60 \% \\
(194)\end{array}$ & $\begin{array}{l}66.11 \% \\
(238)\end{array}$ & $\begin{array}{l}43.42 \% \\
(188)\end{array}$ & $\begin{array}{l}54.24 \% \\
(531)\end{array}$ & $\begin{array}{l}45.79 \% \\
(87)\end{array}$ & $\begin{array}{l}73.92 \% \\
(326)\end{array}$ & $\begin{array}{l}41.20 \% \\
(260)\end{array}$ & $\begin{array}{l}32.63 \% \\
(31)\end{array}$ \\
\hline No & $\begin{array}{l}47.22 \% \\
(552)\end{array}$ & $\begin{array}{l}48.40 \% \\
(182)\end{array}$ & $\begin{array}{l}33.89 \% \\
(122)\end{array}$ & $\begin{array}{l}56.58 \% \\
(245)\end{array}$ & $\begin{array}{l}45.76 \% \\
(448)\end{array}$ & $\begin{array}{l}54.21 \% \\
(103)\end{array}$ & $\begin{array}{l}26.08 \% \\
(115)\end{array}$ & $\begin{array}{l}58.80 \% \\
(371)\end{array}$ & $\begin{array}{l}67.37 \% \\
(64)\end{array}$ \\
\hline
\end{tabular}

Table 1: Student nurse survey results from South and central Kerala, conducted October-

November 2008. 
